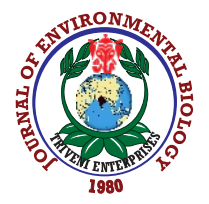

\title{
Micronutrients accumulation under pearl millet-wheat cropping system in response of salinity levels amended with sewage sludge
}

\author{
Ankush', R. Prakash ${ }^{1 *}$, R. Singh', Sachin Kumari ${ }^{3}$ and V. Singh ${ }^{2}$ \\ ${ }^{1}$ Department of Soil Science, Chaudhary Charan Singh Haryana Agricultural University, Hisar-125 004, India \\ ${ }^{2}$ Department of Agronomy, Chaudhary Charan Singh Haryana Agricultural University, Hisar-125 004, India \\ ${ }^{3}$ Department of Chemistry, Chaudhary Charan Singh Haryana Agricultural University, Hisar- 125 004, India \\ *Corresponding Author Email : ramsansanwal@gmail.com
}

\section{Abstract}

Aim: The present study was undertaken to evaluate the effect of sewage sludge and saline water irrigation on micronutrients concentration in pearl millet-wheat cropping system.

Methodology: The trial was conducted during 2017-2019 at Soil Research Farm, CCS Haryana Agricultural University, Haryana in a factorial random block design with three replications. There were three salinity levels of irrigation water, i.e., canal water $\left(0.35 \mathrm{dS} \mathrm{m}^{-1}\right), 8$ and $10 \mathrm{dS} \mathrm{m}{ }^{-1} \mathrm{EC}$ of saline water; and five fertilization levels, i.e., control (no fertilizer), sewage sludge $\left(5\right.$ tha $\left.^{-1}\right)$, SS $\left(5\right.$ tha $\left.^{-1}\right)+50 \%$ RDF, SS $\left(5\right.$ tha $\left.{ }^{-1}\right)+75 \%$ RDF and $100 \%$ RDF. However, sewage sludge was applied in Rabiseasons only.

Results: Based on pooled analysis of two years, micronutrients (Fe, $\mathrm{Mn}$ and $\mathrm{Cu}$ ) concentration in grain and stover/straw of pearl millet and wheat crops significantly reduced on application of saline water irrigation ( $\mathrm{EC}_{\mathrm{iw}} 8$ and $10 \mathrm{dS} \mathrm{m}^{-1}$ ) whereas, $\mathrm{Zn}$ concentration was non significantly affected with salinity levels. However, highest concentration of $\mathrm{Fe}, \mathrm{Mn}$ and $\mathrm{Cu}$ was recorded with canal water irrigation. There was a significant increase in micronutrients $(\mathrm{Fe}, \mathrm{Mn}$ and $\mathrm{Cu}$ ) concentration in both crops with sewage sludge application in comparison of RDF and control treatments but in case of zinc treatment SS $\left(5 t_{\text {ha }}^{-1}\right)+75 \%$ RDF and $100 \%$ RDF were at par with each other. Among treatments, significantly higher concentration of micronutrients was recorded with SS $\left(5 \mathrm{t} \mathrm{ha}^{-1}\right)+75 \%$ RDF treatment being at par with SS $\left(5\right.$ tha $\left.^{-1}\right)+50 \%$ RDF.

Interpretation: Salinity affects micronutrient availability adversely. However, zinc content was not affected significantly. In such case, sewage sludge application may prove a feasible option that serves as a supplement of nutrients as well as sorting out the problem of dumping waste.

Key words: Micronutrients, Pearl millet, Salinity, Sewage sludge, Wheat

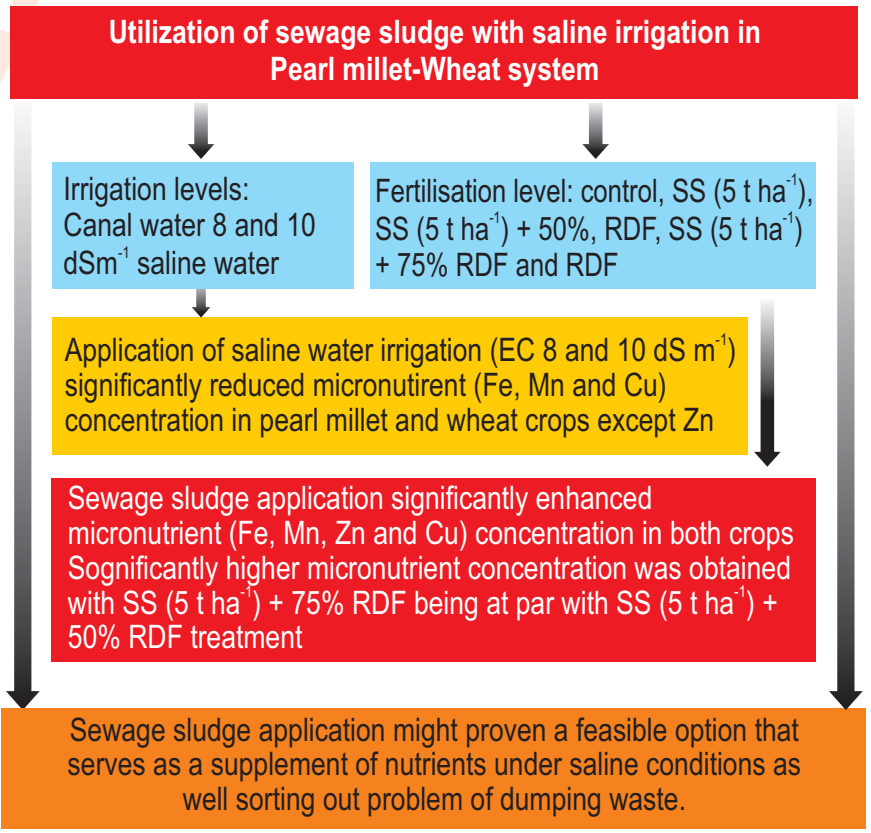

How to cite : Ankush, R. Prakash, R. Singh, Sachin Kumari and V. Singh: Micronutrients accumulation under pearl millet-wheat cropping system in response of salinity levels amended with sewage sludge. J. Environ. Biol., 41, 1641-1647 (2020). 


\section{Introduction}

Pearl millet-wheat cropping system is the most important and popular system under irrigated conditions of arid and semiarid regions of India as well as in South-Western parts of Haryana where pearl millet is grown in Kharif, while wheat in Rabi season. Both crops in the system are very nutrient-exhaustive (Coventry et al., 2011). There is always need to apply large amount of fertilizers on regular basis to have better production (Sheoran et al., 2017).

The ever-increasing urbanization has led to the production of organic wastes like sewage sludge. Sewage sludge is inevitable byproduct obtained from waste treatment plant. At present as a source of waste disposal, the use of sewage sludge in the agricultural field is gaining popularity worldwide (Lamastra et al., 2018). It is generally having compounds of potential environmental value (Mondal et al., 2015). Nowadays, deposition, land filling and incineration are the major ways of disposing of solid waste (Sanchez et al., 2004), only a part of it is used in agriculture. Application of sewage sludge to the soil not only solves the problem of disposal but it also helps in improving soil properties, crop productivity, maintaining soil health and a cleaner environment (Saruhan et al., 2010). The increasing cost of mineral fertilizers and manifolds of sewage sludge production worldwide have led to examine the option of land application of sewage sludge as a source of organic matter and nutrients to the soil. Sewage sludge is rich source of organic matter and various essential plant macronutrients and micronutrients (Meena et al., 2016). It has been found that application of sewage sludge increases micronutrient concentration in wheat (Shahbazi et al., 2017); in rice (Kamal et al., 2013) and spinach (Angin et al., 2016).

There is lack of availability of good quality of water for irrigation so in such cases farmers are forcefully engaged to use poor quality of irrigation water that eventually lead to increase salinity problem in soil. Soil salinity is a major crop production constraint affecting about $77 \mathrm{M}$ ha worldwide. In Haryana, on an average, about 55 percent of the groundwater used for irrigation is of poor quality. Soil salinization has led to decrease nutrient availability, thus limiting crop production and has negative effect on food security (Yadav et al., 2015). Micronutrients availability in soil and plants is variable and controlled by their concentrations in soil solution, soil pH, salinity levels, salt concentrations and crop species etc. The micronutrient availability in saline soil is very complex due to these factors and their interactions (Fageria et al., 2011). However, solubility of micronutrients is low under saline soils (Nouck et al., 2016). There is a need to find alternate option to overcome salinity effects.

Till date, no much efforts have been made on the use of sewage sludge with saline water irrigation in pearl millet-wheat cropping system. The present investigation was carried out to assess the effect of sewage sludge on micronutrient contents in pearl millet and wheat crops using saline water irrigation.

\section{Materials and Methods}

Experimental site: The experiment was conducted at Soil Research Farm, CCS Haryana Agricultural University, Hisar for two years (2017-19). The site belongs to semi-arid, sub-tropics region and is situated at $29^{\circ} 8^{\prime} \mathrm{N}$ latitude and $75^{\circ} 70^{\prime} \mathrm{E}$ longitude at an elevation of $215.2 \mathrm{~m}$ above mean sea level. The whole experimental site $\left(911.25 \mathrm{~m}^{2}\right)$ was divided into 45 plots with an area of $20.25 \mathrm{~m}^{2}$. The soil was sandy loam in texture. The experimental field was laid out in factorial randomly block design and replicated three times.

Treatment details: The experiment consisted of irrigation water of three levels of three salinity levels of irrigation water, i.e., canal water $\left(0.35 \mathrm{dS} \mathrm{m}^{-1}\right), 8$ and $10 \mathrm{dS} \mathrm{m}^{-1} \mathrm{EC}_{\text {iw }}$ of saline water; and five fertilizer treatments, i.e., control (no fertilizer), sewage sludge $\left(\right.$ SS- 5 tha $\left.^{-1}\right)$, SS $\left(5\right.$ tha $\left.^{-1}\right)+50 \%$ RDF, SS $\left(5\right.$ tha $\left.^{-1}\right)+75 \%$ RDF and $100 \%$ RDF.

Agronomic practices: Sewage sludge was applied as basal dose in rabi season only. The portions of N, P and K were applied through urea, di-ammonium phosphate (DAP) and muriate of potash (MOP), respectively. Half of the $\mathrm{N}$ and full portion of $\mathrm{P}$ and $\mathrm{K}$ was applied at the time of sowing of crop and remaining $\mathrm{N}$ was applied after $1^{\text {st }}$ irrigation and recommended dose of zinc through zinc sulphate was applied at sowing time in wheat season only during both years. Varieties HHB 226 and WH 1105 of pearl millet and wheat were taken for the experimentation, respectively. Sowing of crops was done with the help of manual handled plough. Irrigation was applied in both crops according to their package practice adopted in Haryana and desired level of EC was prepared by repeatedly blending of bore well saline water with canal water till to get 8 and $10 \mathrm{dS} \mathrm{m}^{-1} \mathrm{EC}$ salinity level.

Soil, sewage sludge and plant analysis: The soil $\mathrm{pH}_{(1: 2)}$ and $\mathrm{EC}_{(1: 2)}$ were determined with $\mathrm{pH}$ and conductivity meter (Richards, 1954). Sewage sludge was collected from municipal solid waste treatment plant situated at CCS HAU campus, Hisar, Haryana (India). The sewage sludge sample was ground and passed through a $2 \mathrm{~mm}$ sieve. For plant analysis, dried plant samples of pearl millet and wheat crops were chopped down with the help of chopper machine. Thereafter, digestion (with di-acid mixture) is

Table 1: Chemical composition of soil and sewage sludge (domestic)

\begin{tabular}{lll}
\hline Parameter & Soil & Sewage sludge \\
\hline $\mathrm{pH}_{(1.5)}\left(\mathrm{dS} \mathrm{m}^{-1}\right)$ & 8.25 & 7.84 \\
$\mathrm{EC}_{(1.5)}$ & 0.37 & 1.45 \\
Organic carbon (\%) $\left._{\text {Micronutrients }\left(\mathrm{mg} \mathrm{kg}^{-1}\right)}\right)$ & 0.31 & 25.40 \\
$\mathrm{Fe}$ & (DTPA-extractable) & (Total) \\
$\mathrm{Mn}$ & 2.31 & 256.00 \\
$\mathrm{Zn}$ & 4.40 & 103.00 \\
$\mathrm{Cu}$ & 1.37 & 49.02 \\
\hline
\end{tabular}


Table 2: Chemical composition of irrigation water

\begin{tabular}{llll}
\hline Parameter & Canal & Saline water $\left(\mathrm{EC}_{\text {iw }} \mathbf{8} \mathrm{dS} \mathrm{m}^{-1}\right)$ & Saline water $\left(\mathrm{EC}_{\text {iw }} \mathbf{1 0 ~ d S ~ m}^{-1}\right)$ \\
\hline $\mathrm{pH}$ & 7.10 & 7.66 & 7.83 \\
$\mathrm{EC}\left(\mathrm{dS} \mathrm{m}{ }^{-1}\right)$ & 0.35 & 8.17 & 10.09 \\
Soluble ions & & & \\
$\mathrm{Na}^{+}$ & 0.71 & 53.80 & 53.80 \\
$\mathrm{Ca}^{2+}$ & 0.98 & 7.50 & 8.45 \\
$\mathrm{Mg}^{2+}$ & 1.65 & 18.50 & 24.04 \\
$\mathrm{Cl}^{-}$ & 1.35 & 59.6 & 72.80 \\
SAR & 0.62 & 14.90 & 17.15 \\
\hline
\end{tabular}

the primary step in the elemental analysis. The micronutrients (Fe, $\mathrm{Mn}, \mathrm{Mn}$ and $\mathrm{Cu}$ ) concentration in soil, sewage sludge, and plant were determined with the help of atomic absorption spectroscopy (Lindsay and Norvell, 1978).

Irrigation water analysis: Analysis of irrigation water was done following standard methods (Richard, 1954). Sodium content in water was determined by using flame photometer. Calcium and magnesium $\left(\mathrm{Mg}^{2+}\right)$ in water were determined by versenate titration using Eriochrome black-T indicator in the presence of buffer. Chloride $\left(\mathrm{Cl}^{-}\right)$was determined by titrating it with silver nitrate $\left(\mathrm{AgNO}_{3}\right)$ solution using potassium dichromate as an indicator. Sodium adsorption ratio (SAR) measures of the suitability of water for use in agricultural for irrigation purpose, which is calculated by the concentrations of soluble cations ( $\mathrm{Na}^{+}$, $\mathrm{Ca}^{2+}$ and $\mathrm{Mg}^{2+}$ ). SAR was calculated by the formula given by (Todd, 1980)

$$
\mathrm{SAR}=\frac{\mathrm{Na}^{+}}{\sqrt{\frac{\mathrm{Ca}^{2+}+\mathrm{Mg}^{2+}}{2}}}
$$

Statistical analysis: Data were statistically analyzed by adopting the standard statistical methods as explained by Fischer (1950). The level of significance referred to in the results is $\mathrm{P}=0.05$.

\section{Results and Discussion}

The data pertaining to micronutrient concentrations in grain (Table 3) and stover (Table 4) of pearl millet, revealed that application of sewage sludge and saline water irrigation significantly influenced micronutrient concentration in pearl millet except zinc that remained unaffected. Based on pooled analysis, the concentration of $\mathrm{Fe}, \mathrm{Mn}, \mathrm{Zn}$ and $\mathrm{Cu}$ in pearl millet grain ranged from 65.53 to $145.04 ; 57.02$ to $100.74 ; 42.40$ to 68.23 and 3.87 to $8.84 \mathrm{mg} \mathrm{kg}^{-1}$, respectively whereas in pearl millet stover ranged from 138.88 to $234.42 ; 82.02$ to $122.17 ; 53.58$ to 81.02 and 6.73 to $10.94 \mathrm{mg} \mathrm{kg}^{-1}$, respectively. Application of saline water significantly reduced micronutrient contents in pearl millet grain and stover, except for $\mathrm{Zn}$. A significant higher concentration of Fe, $\mathrm{Mn}$ and $\mathrm{Cu}$ in pearl millet grain $\left(124.79,89.09\right.$ and $\left.7.33 \mathrm{mg} \mathrm{kg}^{-1}\right)$ as well as in stover $\left(207.59,121.98\right.$ and $\left.10.28 \mathrm{mg} \mathrm{kg}^{-1}\right)$ was recorded with canal water irrigation $\left(0.35 \mathrm{dS} \mathrm{m}^{-1}\right)$ and lowest with $\mathrm{EC}_{\text {iw }} 10 \mathrm{dS}$ $\mathrm{m}^{-1}$ of saline water irrigation. Application of $10 \mathrm{dS} \mathrm{m}^{-1} \mathrm{EC}$ of saline irrigation caused significant reduction in $\mathrm{Fe}, \mathrm{Mn}$ and $\mathrm{Cu}$ concentration, i.e., 17.0, 17.03 and 15.1 per cent in pearl millet grain and 10.2, 18.9 and 20.6 per cent in pearl millet stover. Among treatments, it was noticed that sewage sludge application significantly increased $\mathrm{Fe}, \mathrm{Mn}, \mathrm{Zn}$ and $\mathrm{Cu}$ concentration in pearl millet grain and stover in comparison to RDF and control treatments. A significantly higher concentration of $\mathrm{Fe}, \mathrm{Mn}, \mathrm{Zn}$ and Cu concentration in pearl millet grain $(145.04,100.74,68.23$ and $\left.8.84 \mathrm{mg} \mathrm{kg}^{-1}\right)$ as well as in stover $(234.42,122.17,81.02$ and 10.94) was obtained with SS $\left(5\right.$ tha $\left.^{-1}\right)+75 \%$ RDF being at par with SS $\left(5 t_{\text {ha }}^{-1}\right)+50 \%$ RDF treatment. The effect of sludge on zinc concentration was at par with RDF of application of zinc sulphate at the time of crop sowing.

Micronutrient ( $\mathrm{Fe}, \mathrm{Mn}, \mathrm{Zn}$ and $\mathrm{Cu}$ ) concentration in grain (Table 5) and straw (Table 6) of wheat crop significantly decreased with the application of 8 and $10 \mathrm{dS} \mathrm{m}^{-1} \mathrm{EC}$ of saline water irrigation. Whereas, zinc content in wheat crop remained affected non significantly. On pooled basis, it was observed that the maximum concentration of $\mathrm{Fe}, \mathrm{Mn}$ and $\mathrm{Cu}$ in grain, i.e., $143.10,94.81$ and $\left.8.13 \mathrm{mg} \mathrm{kg}^{-1}\right)$ as well as in wheat straw (229.73, 134.19 and $\left.10.44 \mathrm{mg} \mathrm{kg}^{-1}\right)$ was obtained in plots irrigated with canal water $\left(0.35 \mathrm{dS} \mathrm{m}^{-1}\right)$. Irrigation with $10 \mathrm{dS} \mathrm{m}^{-1} \mathrm{EC}$ saline water resulted in 12.3, 16.5 and 13.3 per cent reduction in wheat grain and 11.0, 17.7 and 16.4 per cent reduction in wheat straw, respectively. It is clearly seen that micronutrient concentrations in wheat grain and straw ranged from 59.07 to $182.79,51.23$ to $114.74,36.98$ to 77.86 and 3.41 to $10.40 \mathrm{mg} \mathrm{kg}^{-1} ; 122.42$ to $285.32,75.09$ to $157.95,43.60$ to 93.03 and 5.66 to $12.37 \mathrm{mg} \mathrm{kg}^{-1}$, respectively. Among treatments, sewage sludge application resulted in increased micronutrient concentration of wheat grain and straw. However, the maximum concentration in wheat grain as well as wheat straw was recorded with SS $\left(5\right.$ t ha $\left.^{-1}\right)+75 \%$ RDF (182.70, 114.74 and $10.40 \mathrm{mg} \mathrm{kg}^{-1} ; 280.35,157.95$ and $12.37 \mathrm{mg}$ $\left.\mathrm{kg}^{-1}\right)$ being at par with SS $\left(5 \mathrm{tha}^{-1}\right)+50 \%$ RDF treatment. In case of zinc, it was observed that treatments sewage sludge ( 5 tha $\left.^{-1}\right)$, SS $\left(5\right.$ t ha $\left.^{-1}\right)+50 \%$ RDF, SS $\left(5\right.$ t ha $\left.^{-1}\right)+75 \%$ RDF and $100 \%$ RDF were at par with each other for wheat grain and straw. 
Table 3 : Effect of sewage sludge application on micronutrients concentration $\left(\mathrm{mg} \mathrm{kg}^{-1}\right)$ in pearl millet grain under saline water irrigation

\begin{tabular}{|c|c|c|c|c|c|c|c|c|c|c|c|c|}
\hline \multirow[t]{2}{*}{ Treatments } & \multicolumn{3}{|c|}{$\mathrm{Fe}$} & \multicolumn{3}{|c|}{$\mathrm{Mn}$} & \multicolumn{3}{|c|}{$\mathrm{Zn}$} & \multicolumn{3}{|c|}{$\mathrm{Cu}$} \\
\hline & 2017-18 & 2018-19 & Pooled & 2017-18 & 2018-19 & Pooled & 2017-18 & 2018-19 & Pooled & 2017-18 & 2018-19 & Pooled \\
\hline \multicolumn{13}{|l|}{ Salinity levels } \\
\hline $\begin{array}{l}\text { Canal } \\
\left(0.35 \mathrm{dS} \mathrm{m}^{-1}\right)\end{array}$ & 125.36 & 124.22 & 124.79 & 90.59 & 87.60 & 89.09 & 57.97 & 56.21 & 57.09 & 7.53 & 7.13 & 7.33 \\
\hline $8 \mathrm{dS} \mathrm{m}^{-1}$ & 110.27 & 108.25 & 109.26 & 78.95 & 77.91 & 78.43 & 62.19 & 60.01 & 61.10 & 6.73 & 6.65 & 6.69 \\
\hline $10 \mathrm{dS} \mathrm{m}^{-1}$ & 106.42 & 100.71 & 103.57 & 74.36 & 73.46 & 73.91 & 64.47 & 61.65 & 63.06 & 6.18 & 6.25 & 6.22 \\
\hline S.E. & 3.92 & 3.35 & 3.60 & 2.51 & 2.28 & 2.34 & 1.90 & 1.96 & 1.89 & 0.29 & 0.25 & 0.25 \\
\hline C.D. $(p=0.05)$ & 11.36 & 9.70 & 10.42 & 7.28 & 6.59 & 6.77 & NS & NS & NS & 0.83 & 0.73 & 0.74 \\
\hline \multicolumn{13}{|c|}{ Fertilization levels } \\
\hline Control & 73.34 & 57.71 & 65.53 & 64.01 & 50.04 & 57.02 & 48.95 & 35.86 & 42.40 & 4.67 & 3.07 & 3.87 \\
\hline SS $\left(5\right.$ tha $\left.^{-1}\right)$ & 128.51 & 133.90 & 131.21 & 82.56 & 88.02 & 85.29 & 62.17 & 62.62 & 62.40 & 7.28 & 7.80 & 7.54 \\
\hline $\begin{array}{l}\text { SS }\left(5 \text { tha }^{-1}\right)+ \\
50 \% \text { RDF }\end{array}$ & 136.00 & 141.22 & 138.61 & 91.00 & 96.46 & 93.73 & 65.30 & 65.25 & 65.28 & 7.77 & 8.48 & 8.13 \\
\hline $\begin{array}{l}\text { SS }\left(5 \text { tha }^{-1}\right)+ \\
75 \% \text { RDF }\end{array}$ & 143.56 & 146.52 & 145.04 & 97.00 & 104.48 & 100.74 & 67.23 & 69.23 & 68.23 & 8.42 & 9.26 & 8.84 \\
\hline $100 \%$ RDF & 88.68 & 75.96 & 82.32 & 71.92 & 59.27 & 65.60 & 64.07 & 63.49 & 63.78 & 5.92 & 4.78 & 5.35 \\
\hline S.E. & 5.06 & 4.32 & 4.64 & 3.24 & 2.94 & 3.02 & 2.45 & 2.56 & 2.44 & 0.37 & 0.32 & 0.33 \\
\hline C.D. $(p=0.05)$ & 14.67 & 12.53 & 13.45 & 9.39 & 8.51 & 8.74 & 7.11 & 7.42 & 7.06 & 1.07 & 0.94 & 0.95 \\
\hline
\end{tabular}

Table 4 : Effect of sewage sludge application on micronutrients concentration $\left(\mathrm{mg} \mathrm{kg}^{-1}\right)$ in pearl millet stover under saline water irrigation

\begin{tabular}{|c|c|c|c|c|c|c|c|c|c|c|c|c|}
\hline \multirow[t]{2}{*}{ Treatments } & \multicolumn{3}{|c|}{$\mathrm{Fe}$} & \multicolumn{3}{|c|}{$\mathrm{Mn}$} & \multicolumn{3}{|c|}{$\mathrm{Zn}$} & \multicolumn{3}{|c|}{$\mathrm{Cu}$} \\
\hline & 2017-18 & 2018-19 & Pooled & 2017-18 & 2018-19 & Pooled & 2017-18 & 2018-19 & Pooled & 2017-18 & 2018-19 & Pooled \\
\hline \multicolumn{13}{|l|}{ Salinity levels } \\
\hline $\begin{array}{l}\text { Canal } \\
\left(0.35 \mathrm{dS} \mathrm{m}^{-1}\right)\end{array}$ & 211.80 & 203.38 & 207.59 & 125.79 & 118.16 & 121.98 & 69.22 & 67.28 & 68.25 & 10.55 & 10.01 & 10.28 \\
\hline $8 \mathrm{dS} \mathrm{m}^{-1}$ & 194.96 & 188.86 & 191.91 & 106.34 & 102.81 & 104.58 & 72.95 & 71.61 & 72.28 & 8.94 & 8.46 & 8.70 \\
\hline $10 \mathrm{dS} \mathrm{m}^{-1}$ & 187.19 & 185.49 & 186.34 & 101.15 & 96.56 & 98.85 & 74.85 & 74.49 & 74.67 & 8.27 & 8.06 & 8.16 \\
\hline S.E. & 5.64 & 5.36 & 5.33 & 3.98 & 3.47 & 3.56 & 2.19 & 2.03 & 2.06 & 0.38 & 0.31 & 0.33 \\
\hline C.D. $(0.05)$ & 16.35 & 15.53 & 15.43 & 11.52 & 10.05 & 10.32 & NS & NS & NS & 1.10 & 0.89 & 0.94 \\
\hline \multicolumn{13}{|c|}{ Fertilization levels } \\
\hline Control & 154.69 & 123.07 & 138.88 & 91.36 & 72.68 & 82.02 & 59.05 & 48.11 & 53.58 & 7.82 & 5.64 & 6.73 \\
\hline $\mathrm{SS}\left(5\right.$ tha $\left.^{-1}\right)$ & 209.54 & 221.85 & 215.69 & 113.86 & 117.74 & 115.80 & 71.28 & 73.36 & 72.32 & 9.64 & 10.12 & 9.88 \\
\hline $\begin{array}{l}\text { SS }\left(5 \text { tha }^{-1}\right)+ \\
50 \% \text { RDF }\end{array}$ & 219.04 & 230.46 & 224.75 & 122.67 & 125.56 & 124.11 & 76.87 & 78.31 & 77.59 & 10.14 & 10.83 & 10.48 \\
\hline $\begin{array}{l}\text { SS }\left(5 \text { tha }^{-1}\right)+ \\
75 \% \text { RDF }\end{array}$ & 229.10 & 239.86 & 234.48 & 129.00 & 135.33 & 132.17 & 80.27 & 81.78 & 81.02 & 10.58 & 11.29 & 10.94 \\
\hline $100 \%$ RDF & 177.55 & 147.65 & 162.60 & 98.57 & 77.92 & 88.24 & 74.23 & 74.07 & 74.15 & 8.09 & 6.32 & 7.20 \\
\hline S.E. & 7.29 & 6.92 & 6.88 & 5.14 & 4.48 & 4.60 & 2.83 & 2.62 & 2.66 & 0.49 & 0.40 & 0.42 \\
\hline C.D. (0.05) & 21.10 & 20.05 & 19.92 & 14.88 & 12.98 & 13.33 & 8.19 & 7.58 & 7.72 & 1.42 & 1.15 & 1.22 \\
\hline
\end{tabular}

The concentration of $\mathrm{Fe}, \mathrm{Mn}$ and $\mathrm{Cu}$ in grains and stover/straw of pearl millet (Table 3 and 4 ) and wheat (Tables 5 and 6) was significantly reduced on irrigation with saline water and lowest concentration was recorded with application of $10 \mathrm{dS}$ $\mathrm{m}^{-1} \mathrm{EC}_{\mathrm{iw}}$ being at par with $8 \mathrm{dS} \mathrm{m}^{-1} \mathrm{EC}_{\text {iw }}$ of saline water irrigation. The results are in corroboration with the findings of Shaaban and Abou El-Nour (2013) and Chakraborty et al. (2015). The decrease in micronutrient concentration may be attributed to reduced availability of water in roots and in other plant parts (Pandey, 2020) and also, lower solubility of micronutrients under saline environment (Nouck et al., 2016). Whereas, an increased micronutrients concentration in plants was reported by Moreno et al. (2000); Hirpara et al. (2005); Talei et al. (2012). In the present study, zinc content in pearl millet and wheat remained unaffected on irrigation with saline water. Similar results have also been reported by Hu et al. (2000); Hu and Schmidhalter, (2001). Yadav et al. (2015) reported that $\mathrm{Zn}$ concentration in wheat straw remains unaffected on irrigation with saline water as compared to control $\left(0.4 \mathrm{dS} \mathrm{m}^{-1}\right)$. Though it is very difficult to explain the mechanism of salinity influence on micronutrient concentration 
Table 5 : Effect of sewage sludge application on micronutrients concentration $\left(\mathrm{mg} \mathrm{kg}^{-1}\right)$ in wheat grain under saline water irrigation

\begin{tabular}{|c|c|c|c|c|c|c|c|c|c|c|c|c|}
\hline \multirow[t]{2}{*}{ Treatments } & \multicolumn{3}{|c|}{$\mathrm{Fe}$} & \multicolumn{3}{|c|}{$\mathrm{Mn}$} & \multicolumn{3}{|c|}{$\mathrm{Zn}$} & \multicolumn{3}{|c|}{$\mathrm{Cu}$} \\
\hline & 2017-18 & 2018-19 & Pooled & 2017-18 & 2018-19 & Pooled & 2017-18 & 2018-19 & Pooled & 2017-18 & 2018-19 & Pooled \\
\hline \multicolumn{13}{|l|}{ Salinity levels } \\
\hline $\begin{array}{l}\text { Canal } \\
\left(0.35 \mathrm{dS} \mathrm{m}^{-1}\right)\end{array}$ & 143.46 & 142.74 & 143.10 & 93.51 & 96.11 & 94.81 & 64.24 & 62.92 & 63.58 & 8.25 & 8.02 & 8.13 \\
\hline $8 \mathrm{dS} \mathrm{m}^{-1}$ & 129.28 & 129.80 & 129.54 & 83.49 & 85.24 & 84.37 & 68.12 & 66.75 & 67.43 & 7.49 & 7.23 & 7.36 \\
\hline $10 \mathrm{dS} \mathrm{m}^{-1}$ & 124.99 & 125.92 & 125.46 & 78.49 & 79.90 & 79.20 & 70.62 & 68.78 & 69.70 & 7.58 & 6.51 & 7.05 \\
\hline S.E. & 4.12 & 3.73 & 3.90 & 2.41 & 2.50 & 2.45 & 3.34 & 2.00 & 1.95 & 0.31 & 0.29 & 0.29 \\
\hline C.D. $(p=0.05)$ & 11.94 & 10.81 & 11.29 & 6.97 & 7.24 & 7.09 & NS & NS & NS & NS & 0.84 & 0.84 \\
\hline \multicolumn{13}{|c|}{ Fertilization levels } \\
\hline Control & 66.07 & 52.07 & 59.07 & 57.42 & 45.04 & 51.23 & 43.58 & 30.38 & 36.98 & 3.95 & 2.88 & 3.41 \\
\hline $\mathrm{SS}\left(5 \mathrm{tha}^{-1}\right)$ & 163.90 & 172.50 & 168.20 & 92.36 & 105.28 & 98.82 & 70.60 & 71.87 & 71.24 & 9.01 & 9.35 & 9.18 \\
\hline $\begin{array}{l}\text { SS }\left(5 \text { tha }^{-1}\right)+ \\
50 \% \text { RDF }\end{array}$ & 171.16 & 180.60 & 175.88 & 102.07 & 113.16 & 107.62 & 74.23 & 75.56 & 74.90 & 9.78 & 9.85 & 9.82 \\
\hline $\begin{array}{l}S S\left(5 \text { tha }^{-1}\right)+ \\
75 \% \text { RDF }\end{array}$ & 178.47 & 186.93 & 182.70 & 108.06 & 121.41 & 114.74 & 76.38 & 79.34 & 77.86 & 10.25 & 10.54 & 10.40 \\
\hline $100 \%$ RDF & 83.28 & 72.00 & 77.64 & 65.92 & 50.53 & 58.22 & 73.50 & 73.61 & 73.56 & 5.87 & 3.65 & 4.76 \\
\hline S.E. & 5.32 & 4.82 & 5.03 & 3.11 & 3.23 & 3.16 & 2.71 & 2.58 & 2.52 & 0.40 & 0.38 & 0.38 \\
\hline C.D. $(p=0.05)$ & 15.42 & 13.96 & 14.57 & 9.00 & 9.35 & 9.15 & 7.23 & 7.48 & 7.30 & 1.16 & 1.09 & 1.09 \\
\hline
\end{tabular}

Table 6 : Effect of sewage sludge application on micronutrients concentration $\left(\mathrm{mg} \mathrm{kg}^{-1}\right)$ in wheat straw under saline water irrigation

\begin{tabular}{|c|c|c|c|c|c|c|c|c|c|c|c|c|}
\hline \multirow[t]{2}{*}{ Treatments } & \multicolumn{3}{|c|}{$\mathrm{Fe}$} & \multicolumn{3}{|c|}{$\mathrm{Mn}$} & \multicolumn{3}{|c|}{$\mathrm{Zn}$} & \multicolumn{3}{|c|}{$\mathrm{Cu}$} \\
\hline & 2017-18 & 2018-19 & Pooled & 2017-18 & 2018-19 & Pooled & 2017-18 & $2018-19$ & Pooled & 2017-18 & 2018-19 & Pooled \\
\hline \multicolumn{13}{|l|}{ Salinity levels } \\
\hline $\begin{array}{l}\text { Canal } \\
\left(0.35 \mathrm{dS} \mathrm{m}^{-1}\right)\end{array}$ & 233.89 & 225.57 & 229.73 & 134.56 & 133.81 & 134.19 & 76.41 & 74.79 & 75.60 & 10.54 & 10.34 & 10.44 \\
\hline $8 \mathrm{dS} \mathrm{m}^{-1}$ & 215.24 & 206.40 & 210.82 & 118.63 & 116.92 & 117.77 & 80.16 & 80.00 & 80.08 & 9.73 & 9.05 & 9.39 \\
\hline $10 \mathrm{dS} \mathrm{m}^{-1}$ & 207.03 & 200.46 & 203.75 & 111.10 & 109.74 & 110.42 & 82.52 & 81.86 & 82.19 & 9.15 & 8.32 & 8.73 \\
\hline S.E. & 6.19 & 5.98 & 6.06 & 3.39 & 3.66 & 3.45 & 2.26 & 2.55 & 2.38 & 0.30 & 0.34 & 0.31 \\
\hline C.D. $(p=0.05)$ & 17.93 & 17.31 & 17.54 & 9.83 & 10.61 & 9.99 & NS & NS & NS & 0.86 & 0.99 & 0.89 \\
\hline \multicolumn{13}{|c|}{ Fertilization levels } \\
\hline Control & 136.74 & 108.11 & 122.42 & 84.04 & 66.13 & 75.09 & 50.29 & 36.91 & 43.60 & 7.42 & 3.91 & 5.66 \\
\hline SS $\left(5\right.$ tha $\left.^{-1}\right)$ & 251.73 & 262.47 & 257.10 & 133.24 & 146.61 & 139.93 & 83.51 & 86.20 & 84.86 & 10.45 & 11.98 & 11.22 \\
\hline $\begin{array}{l}\text { SS }\left(5 \text { tha }^{-1}\right)+ \\
50 \% \text { RDF }\end{array}$ & 260.77 & 274.27 & 267.52 & 144.10 & 154.87 & 149.49 & 87.55 & 91.01 & 89.28 & 11.61 & 12.52 & 12.06 \\
\hline $\begin{array}{l}\text { SS }\left(5 \text { tha }^{-1}\right)+ \\
75 \% \text { RDF }\end{array}$ & 275.39 & 285.32 & 280.35 & 152.44 & 163.47 & 157.95 & 91.36 & 94.70 & 93.03 & 11.54 & 13.19 & 12.37 \\
\hline $100 \%$ RDF & 168.96 & 123.89 & 146.42 & 93.32 & 69.70 & 81.51 & 85.77 & 85.58 & 85.68 & 8.01 & 4.57 & 6.29 \\
\hline S.E. & 7.99 & 7.72 & 7.82 & 4.38 & 4.73 & 4.45 & 2.92 & 3.29 & 3.07 & 0.38 & 0.44 & 0.40 \\
\hline C.D. $(p=0.05)$ & 23.14 & 22.35 & 22.65 & 12.69 & 13.70 & 12.90 & 8.45 & 9.52 & 8.89 & 1.11 & 1.28 & 1.15 \\
\hline
\end{tabular}

that may be due to relatively small difference between control and salinity treated plants and non-linear relationship exists between micronutrients and concentrations of salts in plants.

The maximum build up of micronutrient concentration in wheat straw and grain was obtained with the application of SS $(5 \mathrm{t}$ $\left.\mathrm{ha}^{-1}\right)+75 \%$ RDF being statistically at par with SS $\left(5 \mathrm{t} \mathrm{ha}^{-1}\right)+50 \%$ RDF and similar effect was noticed for its residual effects in pearl millet crop. This may be due to chemical composition of sewage sludge used for the experiment and ascribed to release of micronutrients from sewage sludge as chelated complex (Latare et al., 2014). The results are in accordance with the findings of Singh (2013) and Jatav et al. (2018). All sewage sludge amended plots obtained significantly higher micronutrient concentration in crops over RDF and control where no supplements were applied. This could be ascribed to increased availability of micronutrients in soil on adding sewage sludge (Swain et al., 2020). However, higher concentration of micronutrients in both the crops was 
noted in RDF treated plots as compared to control, however, the treatments were statistically similar. Which may be due to vigorous growth that would have uptake higher nutrient from the soil. Micronutrient concentration in stover/straw and grain of pearl millet and wheat during 2018-19 was higher than preceding year due to application of sewage sludge in rabi season in each cropping system. Residual effect of sewage sludge in pearl millet crop during both years might have added micronutrient in soil, thereby increasing uptake of micronutrients by pearl millet crops.

It can be concluded from present study that salinity affected micronutrient bioavailability adversely and significantly higher concentration of $\mathrm{Fe}, \mathrm{Mn}$ and $\mathrm{Cu}$ was recorded with canal water irrigation. However, zinc content in pearl millet and wheat crop remained iunaffected. Sewage sludge application resulted in increased micronutrient ( $\mathrm{Fe}, \mathrm{Mn}, \mathrm{Zn}$ and $\mathrm{Cu}$ ) content in both crops and highest was recorded with SS $\left(5\right.$ tha $\left.^{-1}\right)+75 \%$ RDF which was at par with SS $\left(5\right.$ tha $\left.^{-1}\right)+50 \%$ RDF treatment. Thus, application of sewage sludge as a source of fertilizer may prove to be a good alternate, i.e., serving as a supplement of micronutrients along with sorting out the problems of dumping waste.

\section{Acknowledgments}

The authors are sincerely thankful to the Soil Science Department, College of Agriculture, CCS Haryana Agricultural University, Haryana, India for their professional and financial support. The labour and lab technicians are also highly acknowledged for their kind help and support.

\section{References}

Angin, I., R. Aslantas, A. Gunes, M. Kose and G. Ozkan: Effects of sewage sludge amendment on some soil properties, growth, yield and nutrient content of raspberry (Rubus idaeus L.). Erwerbsobstbau, 59, 93-99 (2016).

Chakraborty, K., D. Bhaduri and H.N. Meena: External potassium application improves salinity tolerance by promoting $\mathrm{Na}^{+}-$ exclusion, $\mathrm{K}^{+}$accumulation and osmotic adjustment in contrasting peanut cultivars. PI. Physiol. Biochem., 103, 143-153 (2016).

Coventry, D.R., A. Yadav, R.S. Poswal, R.K. Sharma, R.K. Gupta, R.S. Chhokar, S.C. Gill, V. Kumar, A. Kumar, A. Mehta and S.G.L. Kleemann: Irrigation and nitrogen schkkeduling as a requirement for optimising wheat yield and quality in Haryana, India. Field Crops Res., 123, 80-88 (2011).

Fageria, N.K., H.R. Gheyi and A. Moreira: Nutrient bioavailability in salt affected soils. J. PI. Nutri., 34, 945-962 (2011).

Fischer, R.A.: Statistical methods for Agriculture Research Workers. II ${ }^{\text {nd }}$ Edn., Oliver and Boyand, London (1950).

Hirpara, K.D., P.J. Ramoliya, A.D. Patel and A.N. Pandey: Effect of salinisation of soil on growth and macro- and micronutrient accumulation in seedlings of Butea monosperma (Fabaceae). Ann. Biol., 27, 3-14 (2005).

$\mathrm{Hu}, \mathrm{Y}$. and U. Schmidhalter: Effects of salinity and macronutrient levels on micronutrients in wheat. J. PI. Nutri., 24, 273-281 (2001).

$\mathrm{Hu}$, Y., S. von Tucher and U. Schmidhalter: Spatial distributions and net deposition rates of $\mathrm{Fe}, \mathrm{Mn}$, and $\mathrm{Zn}$ in the elongating leaves of wheat under saline soil conditions. Australian J. PI. Physiol., 27, $5359(2000)$.

Jatav, H.S., S.K. Singh, Y. Singh and O. Kumar: Biochar and sewage sludge application increase yield and micronutrient uptake in rice (Oryza sativa L.). Communi. Soil Sci. Plant Anal. (2018). https://doi.org/10.1080/00103624.2018.1474900

Kamal, A.T.M.M., M.M. Islam, M.S. Hossian and S.M. Ullah: Influence of sewage sludge on yield and mineral contents of rice grain. Bangladesh J. Sci. Res., 26, 57-60 (2013).

Lamastra, L., N.A. Suciu and M. Trevisan: Sewage sludge for sustainable agriculture: contaminants' contents and potential use as fertilizer. Chem. Biol. Tech. Agric., 5, 10 (2018).

Latare, A.M., O. Kumar, S.K. Singh and A. Gupta: Direct and residual effect of sewage sludge on yield, heavy metals content and soil fertility under rice-wheat system. Ecol. Engin., 69, 17-24 (2014).

Lindsay, W.L. and W.A. Norwell: Development of DTPA soil test for zinc, iron, manganese and copper. Soil Sci. Soc. America J., 42, 421428 (1978).

Meena, M.D., P.K. Joshi, H.S. Jat, A.R. Chinchmalatpure, B. Narjary, P. Sheoran and D.K. Sharma: Changes in biological and chemical properties of saline soil amended with municipal solid waste compost and chemical fertilizers in a mustard-pearl millet cropping system. Catena, 140, 1-8 (2016).

Mondal, S., R.D. Singh, A.K. Patra and B.S. Dwivedi: Changes in soil quality in response to short-term application of municipal sewage sludge in a Typic haplustept under cowpea-wheat cropping system. Environ. Nanotech., Monitor. Manag., 4, $37-41$ (2015).

Moreno, D.A., G. Pulgar and L. Romero: Yield improvement in zucchini under salt stress: determining micronutrient balance. Sci. Horti., 86, 175-183 (2000).

Nouck, A.E., V.D. Taffouo, E. Tsoata, D.S. Dibong, S.T. Nguemezi, I. Gouado and E. Youmbi: Growth, biochemical constituents, micronutrient uptake and yield response of six tomato (Lycopersicum esculentum L.) cultivars grown under salinity stress. J. Agron., 15, 58-67 (2016).

Pandey, S.N.: Role of micronutrients in biochemical responses of crops under abiotic stresses. In: Sustainable Agriculture in the Era of Climate Change (Eds.: R. Roychowdhury, S. Choudhary, M. Hasanuzzaman and S. Srivastava). Springer, pp. 93-112 (2020)

Richard, L.A.: Diagnosis and improvement of saline and alkaline soils. USDA Handbook Number 60, Washington D.C. Estimation of available phosphorous in soil by extraction with sodium bicarbonate. Circulars USDA. 939 (1954).

Sanchez, M.E., I.B. Estrada, O. Martinez, J. Martin-Villacorta, A. Aller and $A$. Moran: Influence of the application of sewage sludge on the degradation of pesticides in the soil. Chemosphere, 57, 673-679 (2004).

Saruhan, V., I. Gul and I. Aydin: The effects of sewage sludge used as fertilizer on agronomic and chemical features of bird's foot trefoil (Lotus corniculatus) and soil pollution. Sci. Res. Essays, 5, 2567$2573(2010)$.

Shaaban, M.M. and E.A.A. Abou El-Nour: Nutritional status and growth of wheat plants grown under salinity stress conditions as responded to different nitrogen sources. Amer. J. Plant Physiol., 8, 32-40 (2013).

Shahbazi, F., S. Ghasemi, H. Sodaiezadeh, K. Ayaseh and R. ZamaniAhmadmahmoodi: The effect of sewage sludge on heavy metal concentrations in wheat plant (Triticum aestivum L.). Environ. Sci. Poll. Res., 24, 15634-15644 (2017). 
Sheoran, S., D. Raj, R.S. Antil, V.S. Mor and D.S. Dahiya: Productivity, seed quality and nutrient use efficiency of wheat (Triticum aestivum) under organic, inorganic and integrated nutrient management practices after twenty years of fertilization. Cereal Res. Communi., 45, 315-325 (2017).

Singh, V.: Influence of treated sludge, FYM and fertilizers on yield and uptake of micronutrients in spinach. Ann. Agric. Res., 34, 114-117 (2013).

Swain, A., S. Singh, K. Mohapatra and A. Patra: Effect of sewage sludge application on yield, nutrients uptake and nutrient use efficiency of spinach (Spinacia oleracea L.). Ann. Pl. Soil Res., 22, 305-309 (2020).
Talei, D., M.A. Kadir, M.K. Yusop, A. Valdiani and M.P. Abdullah: Salinity effects on macro and micronutrients uptake in medicinal plant of kings of bitters (Andrographis paniculata Nees.). Pl. Omic J., 5, 271-278 (2012).

Todd, D.K.: Groundwater Hydrology. $2^{\text {nd }}$ Edn., John Wiley and Sons, New York (1980).

Walkley, A. and C.A. Black: Estimation of organic carbon by chromic acid and titration method. Soil Sci., 37, 28-29 (1934).

Yadav, A.K., P.K. Yadav, V. Phogat, A. Tikko and S.S. Yadav: Effect of saline water irrigation on the yield and mineral composition of crops in rice-wheat cropping system. J. Indian Soc. Soil Sci., 63, 276-282 (2015). 